\title{
Changes in Proximal and Distal Tubular Reabsorption Produced by Rapid Expansion of Extracellular Fluid *
}

\author{
John P. Hayslett $\nmid$ Michael Kashgarian, $\$$ and Franklin H. Epstein $\S$ \\ (From the Departments of Internal Medicine and Pathology, Yale University School of \\ Medicine, New Haven, Conn.)
}

\begin{abstract}
Summary. Acute infusions of isotonic saline in the rat cause an increase in glomerular filtration rate and in the excretion of salt and water. The kidney swells, due to expansion of tubular and interstitial volume. Despite the increase in tubular diameter, transit time through the proximal tubules and loops of Henle is decreased, presumably owing to a greatly accelerated rate of tubular flow. Proximal tubular reabsorption, measured in blocked tubules, is inhibited in a way that cannot be ascribed to changes in tubular diameter. The prolongation of proximal reabsorptive half-time is not affected by the administration of aldosterone. It occurs equally in rats chronically loaded with or deprived of salt, and it is therefore not likely that it is influenced by the renal content of renin. In contrast, reabsorption from the distal convoluted tubule is enhanced by saline infusion. This change is observed in segments of tubules blocked with oil and isolated from their glomeruli and thus appears to occur independently of changes in glomerular filtration or tubular flow.
\end{abstract}

\section{Introduction}

Acute infusions of saline provoke a diuresis of water and salt in normal animals. Though such infusions usually increase glomerular filtration rate, sodium excretion in dogs is augmented by saline infusion even when the increment in filtration rate is prevented $(1,2)$. It has been shown that the diuresis is associated with a decrease in the fractional reabsorption of glomerular filtrate in the proximal tubule of dogs (3) and rats (4),

* Submitted for publication January 16, 1967 ; accepted April 13, 1967.

Supported by research grants from the U. S. Public Health Service (AM07369 and HE00834) and the American and Connecticut Heart Associations.

+ Work done during the tenure of a research fellowship supported by training grant T1AM5015 from the U. S. Public Health Service.

$\ddagger U$. S. Public Health Service Research Career Development Award K3-HE 13683.

$\S$ U. S. Public Health Service Research Career Award K6-AM-21578.

Address requests for reprints to Dr. Franklin H. Epstein, Dept. of Internal Medicine, Yale University School of Medicine, New Haven, Conn. although it is not clear whether the absolute rate of sodium reabsorption by the proximal tubule is also reduced in the latter animal.

In the present experiments the mechanism of saline diuresis was investigated by micropuncture in single nephrons of rats. Proximal tubular reabsorption, studied in blocked tubules by stoppedflow microperfusion, was diminished by intravenous administration of isotonic saline. Distal absorption, on the other hand, was accelerated by saline infusion. By virtue of the technique used, these changes were independent of changes in tubular diameter, glomerular filtration, or tubular flow through the nephron being studied. The change in proximal tubular reabsorption wás not influenced by prior salt loading or salt restriction and hence is probably independent of the renin content of the kidney.

\section{Methods}

Male Sprague-Dawley rats weighing 160 to $350 \mathrm{~g}$ were anesthetized with Inactin. ${ }^{1}$ A tracheostomy was

\footnotetext{
1 Promonta, Hamburg.
} 
performed, the bladder was cannulated, and the right ureter was ligated and transected proximally to the tie. The left kidney was exposed, its capsule stripped, and the kidney immobilized in a plastic cup for micropuncture as previously described (5). During surgery, isotonic saline equal to $1 \%$ of the body weight was infused intravenously to compensate for extracellular fluid losses.

Isotonic $\mathrm{NaCl}, 150 \mathrm{mEq}$ per $\mathrm{L}$, was infused at the rate of $1.2 \mathrm{ml}$ per hour before and after the rapid saline infusion. After an equilibration period of 60 to $90 \mathrm{~min}$ utes, isotonic saline equal to $10 \%$ of the body weight was infused over the next 60 minutes. Observations were made before, during, and after the rapid expansion of extracellular fluid with isotonic saline.

Inulin-methoxy- ${ }^{3} \mathrm{H}^{2}$ was used to measure glomerular filtration rate (GFR). After a prime of $50 \mu \mathrm{c}$, inulin ${ }^{3} \mathrm{H}$ was infused at a rate of $50 \mu \mathrm{c}$ per hour. The radioactivity of samples in Bray's solution was determined in a Tri-Carb liquid scintillation spectrometer. The counts were corrected for quenching by using a ${ }^{8} \mathrm{H}$ internal standard. Urine was collected at intervals of approximately 30 minutes, and samples of blood were taken from the tail before and after each collection. Urine collected during the first 15 minutes of rapid saline infusion, while the rate of urine flow was increasing, was discarded.

The time taken by fluid to pass through the first 55 to $60 \%$ of the proximal tubule (proximal transit time) was measured by injecting $0.05 \mathrm{ml}$ of $10 \%$ Lissamine green into the jugular vein. The time from the first appearance of dye on the surface of the kidney (capillary flush) to the disappearance of dye from all proximal convolutions was taken in some experiments as the proximal passage time, as recommended by Steinhausen (6). In other experiments, proximal transit time was estimated by the modification of Gertz, Mangos, Braun, and Pagel (7), in which the end point is taken at the time of the convergence of the columns of dye in proximal tubules before they descend beneath the surface to form pars rectae. Distal transit was measured as the time from the initial blush of dye on the surface of the kidney to the earliest appearance of dye in distal tubules.

The half volume reabsorption time of isotonic saline in stopped-flow microperfusions of single proximal and distal tubules was measured by sequence photomicrography as described by Gertz (8). Segments of single surface proximal or distal tubules were filled with castor oil stained with Sudan black, and a droplet of isotonic saline was introduced into the middle of the oil column. The rate of absorption of the saline was measured by photographing the column of oil at intervals of 3 seconds. The distal tubules were identified as those tubules which filled with Lissamine green after the initial clearing phase and contained concentrated dye.

The diameter of the oil column adjacent to the isolated droplet was measured in enlarged photographs with dividers and expressed in microns by comparison with a stage micrometer photographed at the same magnification.

\footnotetext{
2 New England Nuclear Corp., Boston, Mass.
}

Tubular diameter was measured during free flow by snap freezing the whole kidney at $-70^{\circ} \mathrm{C}$ and freeze substituting with absolute alcohol at the same temperature. Histological sections were prepared and were measured with an ocular filar micrometer. Only tubules cut transversely were chosen for measurement. Tubular pressures were measured by manometry, with a method similar to that used by Flanigan and Oken (9). Pipettes with a beveled tip of $8 \mu$ were filled with $3 \%$ Lissamine green that had been filtered through a $0.45-\mu$ Millipore filter. Zero reading was taken at the water-oil interphase on the surface of the kidney. Pressure was recorded in a water manometer in triplicate as the pressure at which dye did not leave and tubular fluid did not enter the pipette.

For purposes of comparison, intratubular pressure and tubular measurements were made in rats during acute hydronephrosis. In these animals observations were made 30 to 60 minutes after the ureter of the experimental kidney was ligated.

Mean femoral arterial pressure was recorded with a catheter placed in the femoral artery, using a Statham strain gage and a Grass model 7 polygraph.

The possible contribution of the renin-angiotensin system was studied by comparing two groups of rats. The first group was fed a sodium-free artificial diet ${ }^{3}$ and tap water for a period of 3 to 6 weeks. The second group was given the same diet mixed with USP salt mixture XIV to contain $0.07 \mathrm{mEq} \mathrm{Na}$ per $\mathrm{g}$ of diet, and received isotonic $\mathrm{NaCl}$ as drinking water for a similar period. Certain rats from the chronically salt-loaded group were given exogenous aldosterone. A priming dose of 50 to $100 \mu \mathrm{g}$ of aldosterone was given intravenously 60 minutes before micropuncture, and a sustaining dose of $5 \mu \mathrm{g}$ per hour was infused throughout the experiment.

The renin content in the kidneys from the two groups of rats was estimated by the granularity of the juxtaglomerular cells in histological sections stained with Bowie's stain. As shown by others $(10,11)$, an increase in juxtaglomerular granulation, thought to correlate with renal content of renin $(12,13)$, was found in sodiumdeficient rats, and a decrease in juxtaglomerular granularity was seen in chronically salt-loaded rats.

\section{Results}

Urine flow, sodium excretion, glomerular filtration rate, and arterial pressure (Table I, Figure 1). Rapid infusions of saline increased urine flow by 15- to 20 -fold. At the height of the diuresis, urinary sodium amounted to $0.5 \%$ of the filtered load in salt-deficient rats, $1.7 \%$ in the group given aldosterone, and $6.3 \%$ in the chronically salt-loaded animals. Inulin clearance, initially approximately $0.4 \mathrm{ml}$ per minute per kidney per $100 \mathrm{~g}$ body weight, rose with infusion in all groups but re-

\footnotetext{
${ }^{3}$ Nutritional Biochemicals. Cleveland, Ohio.
} 
TABLE I

Effect of saline infusion on glomerular filtration

\begin{tabular}{|c|c|c|c|c|c|c|}
\hline & \multicolumn{3}{|c|}{ GFR } & \multicolumn{3}{|c|}{ Transit time* } \\
\hline & $\begin{array}{c}\text { Renin-rich } \dagger \\
\text { (14 rats) }\end{array}$ & $\underset{\text { (13 rats) }}{\text { Renin-poort }}$ & $\begin{array}{c}\text { Aldosteronet } \\
\text { (7 rats) }\end{array}$ & $\begin{array}{c}\text { Renin-rich } \\
\text { (14 rats) }\end{array}$ & $\begin{array}{c}\text { Renin-poor } \\
\text { (10 rats) }\end{array}$ & $\begin{array}{c}\text { Aldosterone } \\
\text { (7 rats) }\end{array}$ \\
\hline $\begin{array}{c}\text { Control } \\
\text { period }\end{array}$ & $\begin{array}{l}479 \pm 59 \ddagger \\
(\mathrm{n}=21)\end{array}$ & $\begin{array}{c}\mu l / \min / 100 \mathrm{~g} \text { body } w t \\
495 \pm 50 \\
(\mathrm{n}=18)\end{array}$ & $\begin{array}{l}366 \pm \\
(n=7)\end{array}$ & $\begin{array}{c}100 \\
(n=20)\end{array}$ & $\begin{array}{c}\% \text { of control } \\
100 \\
(n=13)\end{array}$ & $\begin{array}{c}100 \\
(n=14)\end{array}$ \\
\hline $\begin{array}{l}30 \text { to } 60 \mathrm{~min} \\
\text { after start } \\
\text { of infusion }\end{array}$ & $\begin{array}{l}666 \pm 22 \S \\
(n=20)\end{array}$ & $\begin{array}{l}826 \pm 180 \S \\
(n=17)\end{array}$ & $\begin{array}{l}933 \pm 409 \S \\
(n=7)\end{array}$ & $\begin{array}{l}70 \pm 5 \S \\
(n=9)\end{array}$ & $\begin{array}{l}62 \pm 3 \S \\
(n=9)\end{array}$ & $\begin{array}{l}73 \pm 48 \\
(n=5)\end{array}$ \\
\hline $\begin{array}{l}60 \text { to } 90 \mathrm{~min} \\
\text { after start } \\
\text { of infusion }\end{array}$ & $\begin{array}{l}536 \pm 47 \S \\
(\mathrm{n}=27)\end{array}$ & $\begin{array}{l}383 \pm \\
(n=18)\end{array}$ & $\begin{array}{l}629 \pm 106 \S \\
(n=14)\end{array}$ & $\begin{array}{l}64 \pm 6 \S \\
(n=11)\end{array}$ & $\begin{array}{l}64 \pm 68 \\
(n=7)\end{array}$ & $\begin{array}{l}75 \pm 8 \S \\
(n=11)\end{array}$ \\
\hline $\begin{array}{l}90 \text { to } 120 \mathrm{~min} \\
\text { after start } \\
\text { of infusion }\end{array}$ & & & & & & \\
\hline
\end{tabular}

* These values are given as per cent of control in order to encompass the results obtained by the two techniques used.

$\dagger$ Renin-rich = chronically salt depleted; renin-poor = chronically salt loaded; aldosterone = chronically salt loaded and given exogenous aldosterone.

$\ddagger$ Values represent means \pm standard errors; $n=$ number of observations:

$\$$ Means significantly different from control $p<0.001$.

II Means not different from control $p>0.9$.

turned to or toward control levels during the hour after infusion, at a time when urine flow remained high. Mean femoral arterial blood pressure averaged $100 \mathrm{~mm} \mathrm{Hg}$ and did not change with rapid saline infusion.

Transit time (Table I, Figure 2). Proximal transit time fell during saline diuresis in each group of rats to 60 to $80 \%$ of the control value. The time taken by fluid to transverse the proximal tubules decreased after infusion from a control value of $19.0 \pm 0.9$ seconds (mean \pm standard error) to $13.5 \pm 2.0$ seconds as estimated by the method of Steinhausen and from $12.8 \pm$ 0.7 : seconds to $10.4 \pm 0.3$ seconds using the end point suggested by Gertz. Since the proximal tubules were visibly dilated (see below), this decrease in transit time presumably reflected an increased rate of flow through the tubules. Passage time to the distal tubules was similarly decreased by infusion, from $66.9 \pm 2.4$ seconds before infusion to $40.3 \pm 0.8$ seconds afterwards.

Droplet reabsorption in the proximal tubule (Table I, Figure 3). The reabsorption of stationary droplets of isotonic saline by proximal tubules was clearly prolonged by rapid expansion of extracellular fluid. Half-time of reabsorption rose significantly from a control value of $8.5 \pm$ 0.24 seconds (mean \pm standard error) in rats on a salt-free diet to $11.9 \pm 0.51$ seconds $(\mathrm{p}<0.001)$, and from $8.7 \pm 0.24$ to $11.9 \pm 0.42$ seconds in rats previously salt loaded $(\mathrm{p}<0.001)$. Similar changes were seen in animals treated with exogenous aldosterone. Neither the salt content of the diet nor injections of aldosterone altered the initial reabsorptive half-time or its response to acute intravenous loads of saline.

Since the absolute rate of sodium reabsorption studied by the split droplet technique is proportional to the volume of the isolated droplet as well as to the half-time of disappearance, the diameter of the isolated droplet was measured before and after saline infusion. Tubules filled with oil always appear distended when compared with the surrounding tubules in which free flow is proceeding. No difference was found in the droplet diameter of tubules thus distended with oil before and after saline loading. The prolongation of halftime that was observed therefore represents an absolute decrease in the reabsorption of sodium and water from tubules blocked with oil, as a consequence of rapid expansion of the extracellular fluids with saline.

If it is assumed purely for the purpose of calculation that reabsorption of tubular fluid during free flow has the same rate constant as that measured during stopped perfusion, as suggested by Gertz (7), an approximation can be obtained of the fraction of glomerular filtrate reabsorbed by 
TABLE I

rate $(G F R)$ and proximal tubular function

\begin{tabular}{|c|c|c|c|c|c|c|c|}
\hline \multicolumn{3}{|c|}{ Half-time of reabsorption $\left(t_{\xi}\right)$} & \multicolumn{2}{|c|}{ Diameter of isolated droplet } & \multicolumn{3}{|c|}{ Urine volume } \\
\hline $\begin{array}{c}\text { Renin-rich } \\
\text { (14 rats) }\end{array}$ & $\begin{array}{l}\text { Renin-poor } \\
\text { (13 rats) }\end{array}$ & $\begin{array}{c}\text { Aldosterone } \\
\quad \text { (9 rats) }\end{array}$ & $\begin{array}{c}\text { Renin-rich } \\
\text { (10 rats) }\end{array}$ & $\begin{array}{c}\text { Renin-poor } \\
\text { (9 rats) }\end{array}$ & $\begin{array}{c}\text { Renin-rich } \\
\text { (10 rats) }\end{array}$ & $\begin{array}{c}\text { Renin-poor } \\
\text { (10 rats) }\end{array}$ & $\begin{array}{l}\text { Aldosterone } \\
\text { (7 rats) }\end{array}$ \\
\hline \multicolumn{3}{|c|}{ seconds } & \multicolumn{2}{|c|}{$\mu$} & & $\mu l / \min /$ kidney & \\
\hline $\begin{array}{l}8.5 \pm 0.24 \\
(n=47)\end{array}$ & $\begin{array}{l}8.7 \pm 0.24 \\
(n=47)\end{array}$ & $\begin{array}{l}8.58 \pm 0.32 \\
(n=27)\end{array}$ & $\begin{array}{l}27.4 \pm 0.4 \\
(n=26)\end{array}$ & $\begin{array}{l}27.8 \pm 0.3 \\
(n=15)\end{array}$ & $\begin{array}{l}1.5 \pm 0.2 \\
(n=16)\end{array}$ & $\begin{array}{l}1.5 \pm 0.8 \\
(n=17)\end{array}$ & $\begin{array}{l}1.3 \pm \\
(n=9)\end{array}$ \\
\hline $\begin{array}{l}11.0 \pm 0.57 \S \\
(n=31)\end{array}$ & $\begin{array}{l}11.5 \pm 0.52 \S \\
(n=23)\end{array}$ & $\begin{array}{l}12.0 \pm 1.08 \\
(n=12)\end{array}$ & $\begin{array}{l}26.3 \pm 0.3 \| \\
(n=22)\end{array}$ & $\begin{array}{l}27.8 \pm 0.4 \| \\
(n=15)\end{array}$ & $\begin{array}{l}21.8 \pm 11.78 \\
(n=17)\end{array}$ & $\begin{array}{l}19.7 \pm 4.3 \S \\
(n=15)\end{array}$ & $\begin{array}{l}32.7 \pm 10.98 \\
(n=11)\end{array}$ \\
\hline $\begin{array}{l}11.9 \pm 0.51 \S \\
(n=22)\end{array}$ & $\begin{array}{l}11.9 \pm 0.42 \S \\
(n=30)\end{array}$ & $\begin{array}{l}11.3 \pm 0.368 \\
(n=30)\end{array}$ & $\begin{array}{l}26.3 \pm 0.4 \| \\
(n=18)\end{array}$ & $\begin{array}{l}28.1 \pm 0.5 \| \\
(n=15)\end{array}$ & $\begin{array}{l}19.9 \pm 6.8 \S \\
(n=16)\end{array}$ & $\begin{array}{l}18.0 \pm 4.08 \\
(n=15)\end{array}$ & $\begin{array}{l}25.8 \pm 6.5 \S \\
(n=14)\end{array}$ \\
\hline $\begin{array}{l}11.3 \pm 0.72 \S \\
(n=9)\end{array}$ & $\begin{array}{l}11.9 \pm 0.95 \S \\
(n=12)\end{array}$ & & & & & & \\
\hline
\end{tabular}

proximal tubules using the half-time of reabsorption of the split droplet and the time taken by dye to pass through the proximal tubules by the method of Gertz. This calculated figure averaged $66 \%$ in control rats and $45 \%$ after saline infusion.
It is interesting to see how closely these values correspond to those obtained from actual determinations of inulin in proximal tubular fluid and plasma during free flow by Cortney, Mylle, Lassiter, and Gottschalk (4), who found $67 \%$ of glo-

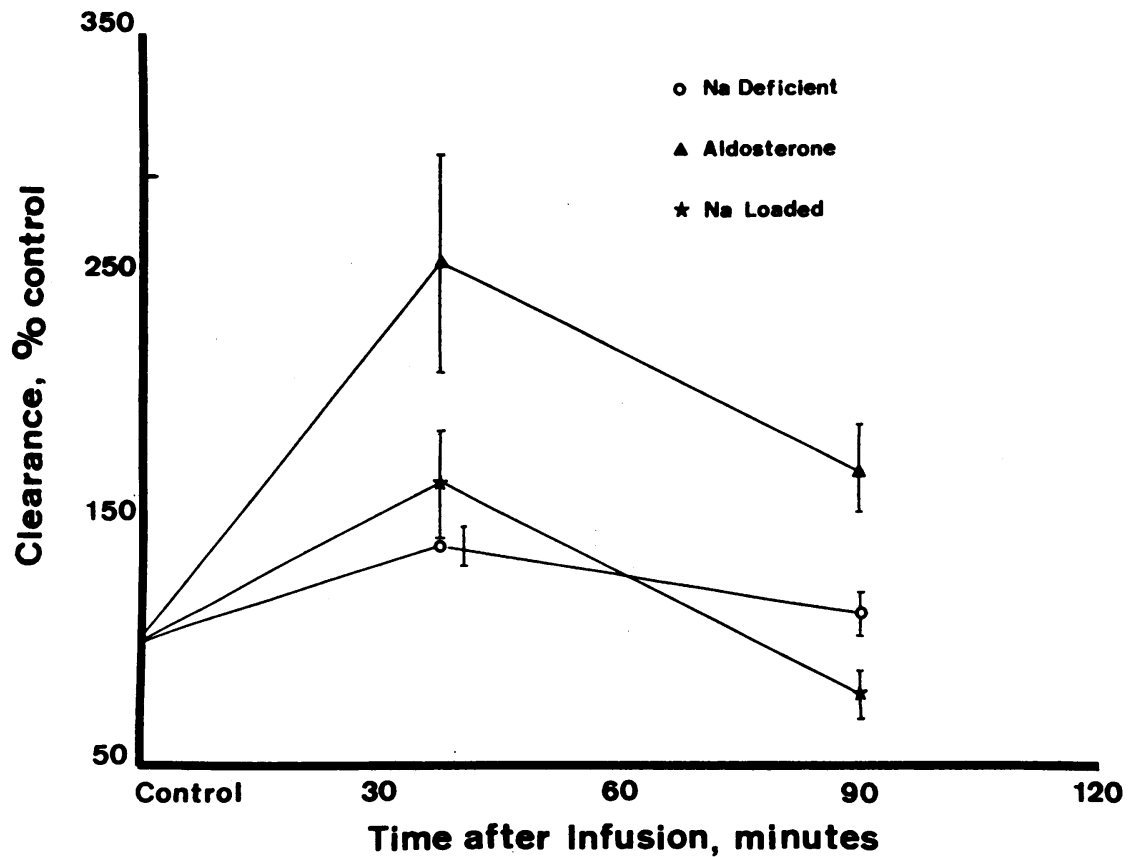

Fig. 1. Change in glomerular filtration rate (GFR) produced by saline inFUsion. Percentage change in GFR (inulin clearance) after rapid saline infusion in three groups of rats. Values are expressed as per cent of GFR in the control period. The Figure shows means and standard errors. 


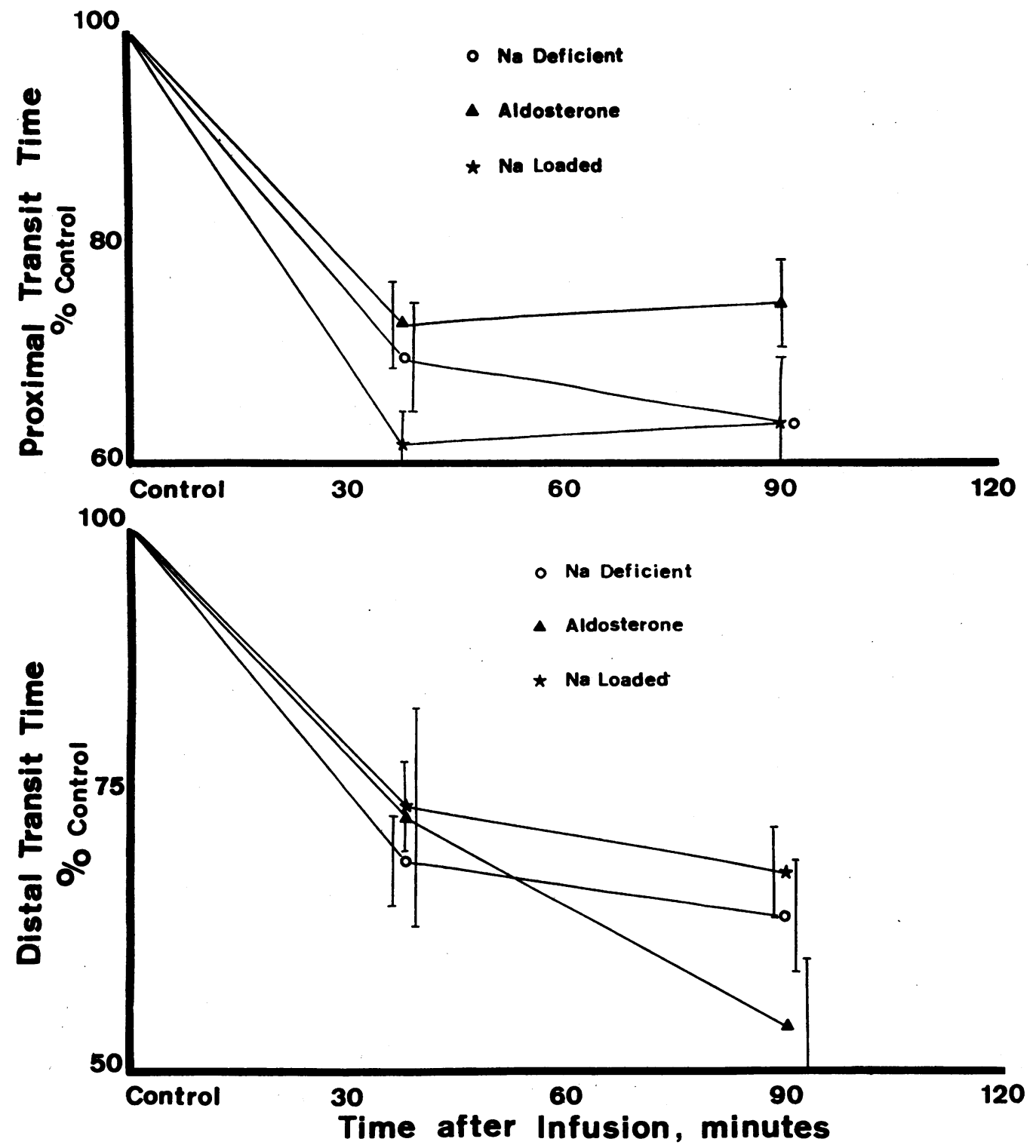

Fig. 2. Changes in transit time in proximal and distal tubules produced by saline infusion. Both proximal and distal passage times decreased after rapid expansion of the extracellular fluid. Values are means \pm standard errors and are expressed as per cent of control.

merular filtrate reabsorbed by the proximal tubule in nondiuretic rats and $42 \%$ after istonic saline loading.

Tubular diameter during free flow (Table II, Figure 4). The kidney swells visibly during rapid infusion of saline. Snap frozen histological sections of the cortex (Figure 4) from animals sacrificed at the end of the 60-minute infusion show that there is expansion of the tubular lumina and of the interstitial space. The average diameter of the proximal tubular lumen was $21.6 \pm 0.6 \mu$ (mean \pm standard error) in kidneys from control rats and $27.1 \pm 0.8 \mu$ in animals undergoing saline diuresis. The increase in luminal area occurs at the expense of the epithelial cells lining the tubule, which appear flattened. The outside diameter of the tubule is unchanged by saline diuresis. These changes in tubular diameter seen during free flow contrast with the observations recorded above in tubules filled with oil in which split droplet mea- 


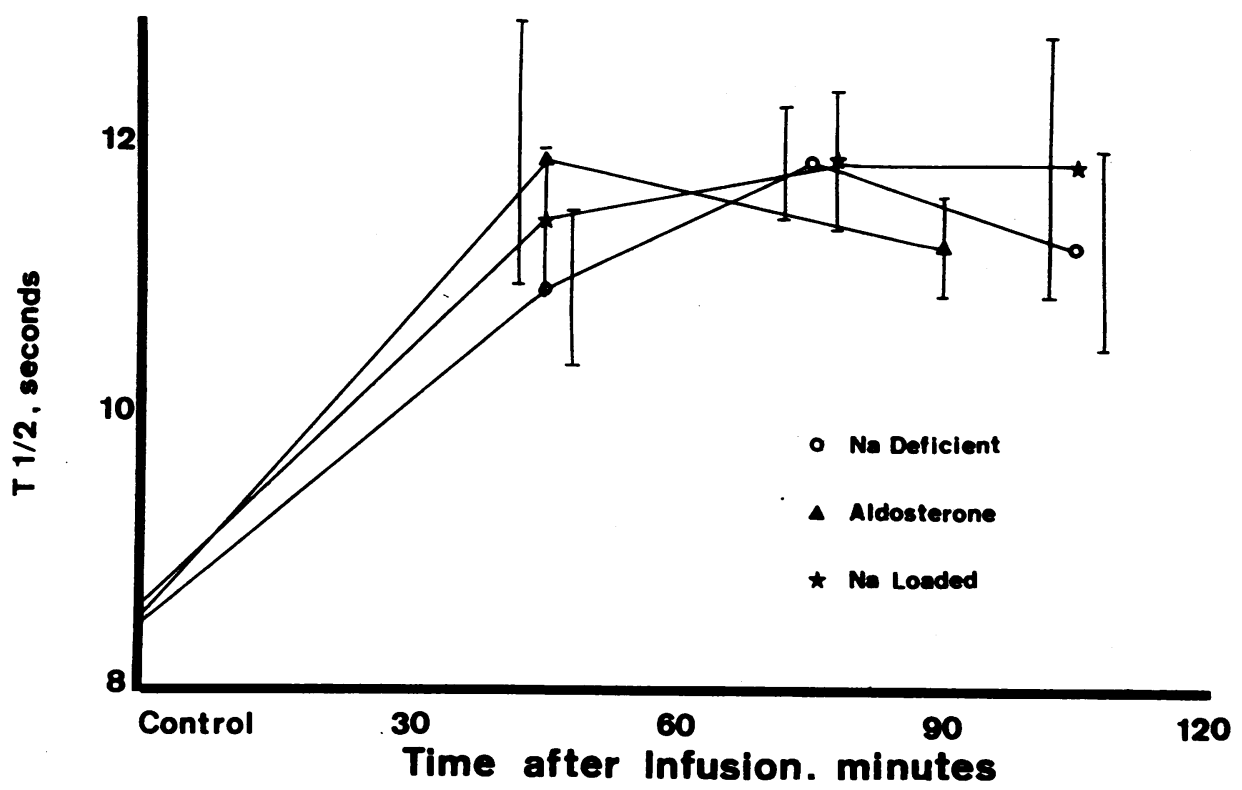

Fig. 3. Changes in Reabsorptive half-time ( $t_{\xi}$ ) in the proximal tUbUle produced by RAPID SALINE INFUSION. Half-time was prolonged in all groups of rats after rapid expansion of extracellular fluid. Values are means \pm standard errors.

surements were made. The latter tubules were apparently maximally distended by the oil droplet, and no difference was seen after infusion with saline.

Proximal tubular pressure (Table II). Swelling of the decapsulated kidney during saline diuresis was not accompanied by measurable changes in intraluminal pressures within the proximal tubule. Average proximal tubular pressure in nondiuretic rats was $15.9 \pm 0.4 \mathrm{~cm} \mathrm{H}_{2} \mathrm{O}$ (mean \pm standard error) and in saline-loaded animals 14.9 土0.6. Care was taken in each experiment to make sure that the tip of the micropuncture pipette was not occluded. Clamping the ureter produced a prompt rise in proximal tubular pressure, which reached $57.1 \pm 4.3 \mathrm{~cm} \mathrm{H}_{2} \mathrm{O}$ in rats loaded with saline.

Droplet reabsorption in the distal tubule (Table $I I I)$. In contrast to the slowing of reabsorption seen in the proximal tubule, the reabsorption time of a droplet of saline placed in an oil-filled segment of distal tubule was shortend by saline diuresis. Half-time of reabsorption with the split droplet technique averaged $38.4 \pm 2.3$ seconds in the distal tubule of control rats and decreased to $29.7 \pm 1.0$ seconds when saline was infused. As in the proximal tubule, the diameter of the isolated droplet was the same before and after saline loading, indicating that changes in reabsorption half-time reflected changes in the absolute volume of fluid absorbed from the droplet.

\section{Discussion}

The increase in urinary excretion of sodium and water provoked in normal animals by acute expansion of the extracellular fluid appears to be caused primarily by changes in glomerular filtration rate and proximal tubular reabsorption. Cortney and associates (4) showed that infusions

TABLE II

Effect of saline loading on proximal tubular diameter and intratubular pressures

\begin{tabular}{|c|c|c|c|}
\hline & $\begin{array}{l}\text { Luminal } \\
\text { diameter }\end{array}$ & $\begin{array}{c}\text { Peritubular } \\
\text { diameter }\end{array}$ & $\begin{array}{l}\text { Intratubular } \\
\text { pressure }\end{array}$ \\
\hline & $\mu$ & $\mu$ & $\mathrm{cm} \mathrm{H}_{2} \mathrm{O}$ \\
\hline Control & $\begin{array}{c}21.6 \pm 0.6^{*} \\
(n=50)\end{array}$ & $\begin{array}{c}40.7 \pm 1.0 \\
(n=50)\end{array}$ & $\begin{array}{r}15.9 \pm 0.4 \\
(n=24)\end{array}$ \\
\hline Saline-loaded & $\begin{array}{c}27.1 \pm 0.8 \dagger \\
(n=41)\end{array}$ & $\begin{array}{c}41.6 \pm 0.7 \ddagger \\
(n=40)\end{array}$ & $\begin{array}{c}14.9 \pm 0.6 \ddagger \\
(n=31)\end{array}$ \\
\hline $\begin{array}{l}\text { Acute } \\
\text { hydronephrosis }\end{array}$ & $\begin{array}{c}25.4 \pm 0.6 \dagger \\
(n=39)\end{array}$ & $\begin{array}{c}38.5 \pm 0.6 t \\
(n=40)\end{array}$ & $\begin{array}{c}18.5 \pm 0.5 \dagger \\
(n=37)\end{array}$ \\
\hline $\begin{array}{l}\text { Acute hydro- } \\
\text { nephrosis and } \\
\text { saline loading }\end{array}$ & & & $\begin{array}{c}57.1 \pm 4.3 \dagger \\
(n=18)\end{array}$ \\
\hline
\end{tabular}

*Values refer to means \pm standard errors; $n=$ number of observations.

Significantly different from control $\mathrm{p}<0.001$.

$\ddagger$ Not different from control $(p>0.3)$. 


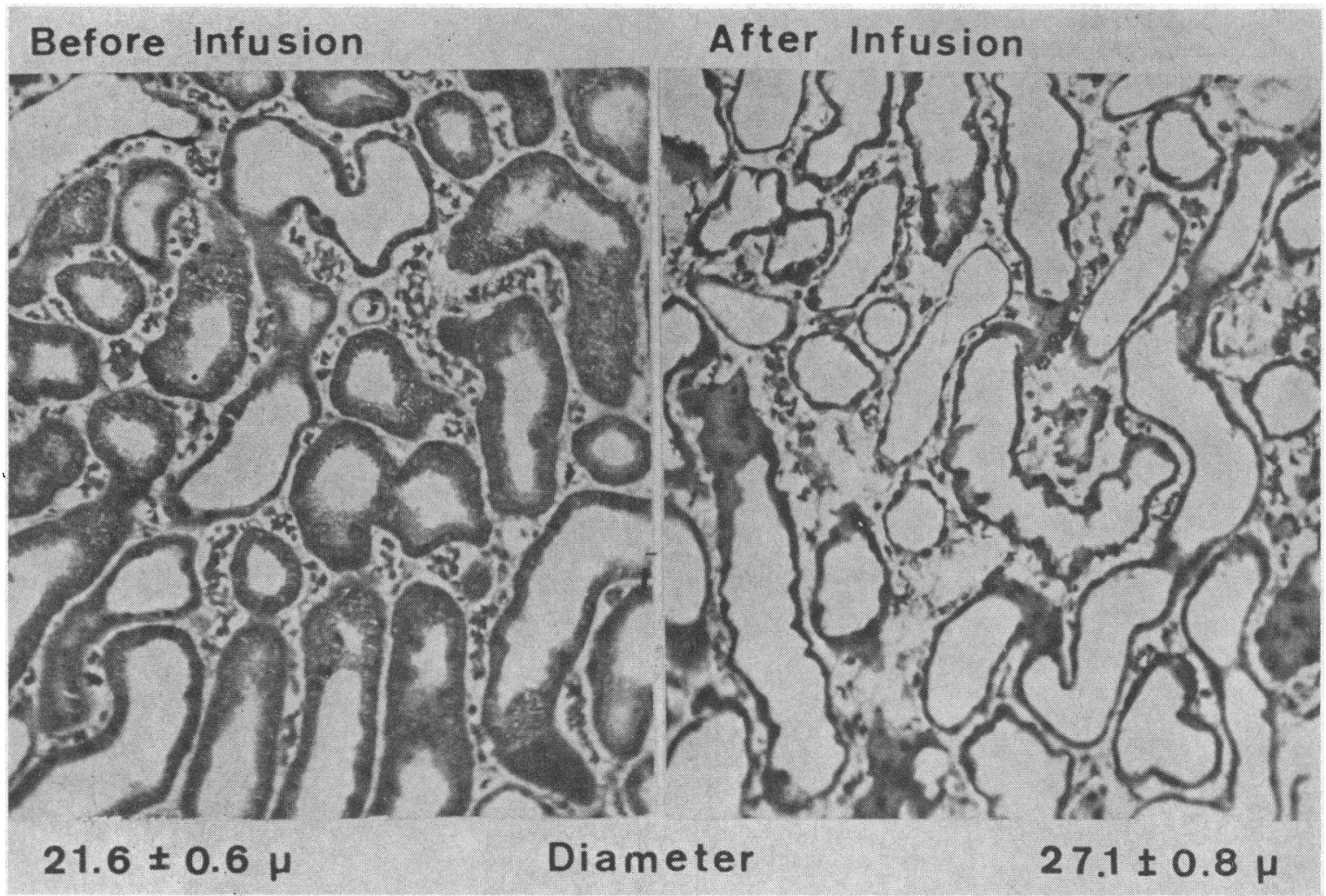

Fig. 4. PhOtomicrographS OF SNAP FROZEN KIDNEYS BEFoRe AND AFTER SALINE INFUSION. Luminal diameter of proximal tubules is given as mean \pm standard error. Note the dilatation of the lumina at the expense of cell height (original magnification $80 \times$ ).

of isotonic saline in rats were accompanied by increases in glomerular filtration rate and parallel decreases in fractional reabsorption of glomerular filtrate, so that the absolute quantity of fluid reabsorbed by the proximal tubule was estimated to remain roughly the same, and the entire increment in fluid filtered was delivered to the distal nephron. It is quite clear, however, at least in the $\mathrm{dog}$, that renal excretion of sodium may be induced by saline infusions even when a rise in glomerular filtration is prevented. By puncturing the proximal tubule of exposed kidneys in dogs, Dirks, Cirksena, and Berliner ( 3 ) demonstrated that the decrease in fractional reabsorption of glomerular

TABLE III

Effect of saline infusion on distal tubular function

\begin{tabular}{|c|c|c|c|c|}
\hline & \multicolumn{2}{|c|}{ Transit time } & \multirow{2}{*}{$\begin{array}{l}\text { Half-time of } \\
\text { reabsorption }\left(\mathrm{t}_{\mathrm{y}}\right) \\
\text { Normal diet } \\
(6 \text { rats })\end{array}$} & \multirow{2}{*}{$\begin{array}{l}\text { Diameter of } \\
\text { isolated droplet } \\
\text { Normal diet } \\
\quad(6 \text { rats })\end{array}$} \\
\hline & $\begin{array}{c}\text { Renin-rich* } \\
\text { (10 rats) }\end{array}$ & $\begin{array}{c}\text { Renin-poor* } \\
\text { (10 rats) }\end{array}$ & & \\
\hline & \multicolumn{2}{|c|}{ \% of control } & seconds & $\mu$ \\
\hline Control period & $\begin{array}{c}100 \\
(n=10)\end{array}$ & $\begin{array}{c}100 \\
(n=10)\end{array}$ & $\begin{array}{c}38.4 \pm 2.3 \ddagger \\
(\mathrm{n}=41)\end{array}$ & $\begin{array}{c}28.9 \pm 0.1 \\
(n=27)\end{array}$ \\
\hline $\begin{array}{l}60 \text { to } 120 \mathrm{~min} \\
\text { after start } \\
\text { infusion }\end{array}$ & $\begin{array}{c}59 \pm 3.4 \dagger \\
(\mathrm{n}=9)\end{array}$ & $\begin{array}{c}68.0 \pm 4.0 \dagger \\
(n=18)\end{array}$ & $\begin{array}{c}29.7 \pm .1 .0 \dagger \\
(n=33)\end{array}$ & $\begin{array}{c}28.1 \pm 0.1 \S \\
(n=27)\end{array}$ \\
\hline
\end{tabular}

${ }^{*}$ Renin-rich $=$ chronically salt-depleted rats; renin-poor $=$ chronically salt-loaded rats.

$\dagger$ Means different from control $(p<0.001)$.

† Values refer to means \pm standard errors; $n=$ number of observations.

$\S$ Means not different from control $(p>0.9)$. 
filtrate induced by saline infusion persisted even when over-all glomerular filtration rate was artificially lowered by clamping the renal artery. Although in the present experiments glomerular filtration rate rose initially when saline was infused, it fell to or below control values in some rats after the infusion was completed. Nevertheless, diuresis persisted (Figure 1), emphasizing the role of altered tubular reabsorption in producing the diuresis. The results of these experiments clarify some aspects of the mechanism of this change in tubular behavior.

The split droplet technique of Gertz measures reabsorption in a segment of tubule isolated with oil in such a way that the transfer rate of water cannot be affected by glomerular filtration rate or tubular flow through the nephron being studied. Infusions of saline greatly prolonged droplet reabsorption time and hence reduced net sodium reabsorption by proximal tubular epithelial cells. By virtue of the technique used, this pronounced effect upon tubular reabsorption was independent of glomerular filtration rate and tubular flow. The administration of aldosterone did not change this response, a result consistent with the failure of mineralocorticoids to alter natriuresis in the dog when saline is infused $(1,2)$. Similar results with the split droplet technique in the proximal tubule have been obtained by Landwehr, Klose, and Giebisch (14) and Rector, Sellman, Martinez-Maldonado, and Seldin (15).

A humoral influence on the proximal tubule has been invoked to explain the natriuresis of saline infusion $(1,16,17)$. A reasonable locus for the elaboration of such a hormone is the juxtaglomerular apparatus. Indeed, Leyssac has suggested that angiotensin may play a physiological role in inhibiting tubular reabsorption of sodium and promoting salt excretion through a direct action upon renal tubular cells $(18,19)$, even though intratubular or peritubular injection of angiotensin does not appear to alter the halftime of resorption of an isolated droplet of saline in the proximal tubule (20). In the present experiments, rats chronically deprived of sodium were compared with rats chronically loaded with sodium. In the former group, renal stores of renin were high and in the latter, the juxtaglomerular apparatus was depleted of granules. Both groups responded similarly to rapid saline infusion. The inhibition of proximal tubular reabsorption that is brought about by saline infusion is therefore not influenced by the renal content of renin, and it seems likely that it is independent of the renin-angiotensin system.

It has been proposed that alterations in tubular diameter play a controlling role in determining proximal tubular reabsorption, presumably by influencing the volume of tubular contents and the area available for sodium flux across tubular membranes $(7,15,21,22)$. It is clear from the present experiments that the inhibition of proximal reabsorption induced by saline infusion was not a direct result of a reduction in tubular diameter. The diameter of isolated proximal tubules blocked with oil and filled with saline was unchanged by intravenous infusion, yet reabsorption of the droplet was significantly prolonged. During free flow, proximal tubules were obviously more distended after saline infusion than before, when they were reabsorbing less, not more, fluid.

Although proximal tubular volume increased with saline loading, the increase was not proportionate to the increase in tubular flow, as evidenced by the shortened proximal transit time. Rector and co-workers have suggested that proximal tubular absorption during saline infusion is partly governed by the ratio of tubular volume to glomerular filtration rate (15). This ratio, calculated from transit time and tubular fluid/plasma inulin, declined during saline diuresis in their experiments. The fact that proximal tubules are obviously dilated during free flow after saline infusion does not, of course, eliminate the possibility that if they were distended even further, tubular reabsorption of salt and water would increase and diuresis would cease. In this sense, tubular diameter might be thought of as influencing the mechanism of saline diuresis, as suggested by Rector and associates (15). A disproportion between tubular volume and GFR is probably not essential for saline diuresis, however, since in the experiments of Landwehr and co-workers, proximal transit time was unchanged after infusions of saline sufficient to reduce proximal absorption and to provoke a diuresis $(14,23)$.

Increases in mean arterial pressure perfusing the kidney have been reported to reduce tubular reabsorption of $\mathrm{Na}$ (24-27), even when tubular flow is stopped (28). Mean femoral arterial pressure, however, was not affected by the amounts of 
saline infused in our experiments. It is interesting that there was no measurable change in pressure within proximal tubules when saline was infused, presumably because only an infinitesimal change in the transtubular pressure gradient was necessary to produce the observed degree of tubular dilatation.

In contrast to the diminution in sodium and water reabsorption in the blocked proximal tubule that was provoked by saline infusion, studies with the split droplet technique in the distal convoluted tubules showed an increase in net tubular reabsorption by approximately one-third, reflected in a $25 \%$ fall in reabsorption half-time. The concentration of sodium in distal tubular fluid is normally lower than in plasma. Because the concentration of sodium in the shrinking droplet was not measured before and after saline infusion, it is not entirely clear whether sodium reabsorption by distal tubular segments increased in proportion to the increase in reabsorption of water. Nevertheless, it is likely that some increase in sodium absorption occurred, since in nondiuretic rats the lowest concentration of sodium reached in droplets of isotonic saline placed in isolated oil-blocked segments of distal tubules by Malnic, Klose, and Giebisch varied only from $0.66 \pm 0.07$ times plasma concentration in the early portion to $0.89 \pm 0.13$ in the late distal tubule (29). Whether distal reabsorption of sodium during free flow is increased by saline loads is not yet established, but seems likely from indirect evidence.

An increase in sodium reabsorption in the distal tubule after expansion of the extracellular fluid was postulated by Rector, Van Giesen, Kiil, and Seldin, who found an increase in free water clearance together with an increase in urine flow and sodium excretion when massive infusions were given under conditions of fixed lowered filtration rate and maximal suppression of antidiuretic hormone (30). In the micropuncture experiments of Dirks and associates, the magnitude of depression of proximal tubular reabsorption compared with the ultimate sodium diuresis that occurred suggested to these authors that distal reabsorption of sodium was enhanced during saline administration (3). The present study provides a direct demonstration of enhanced reabsorption in the distal convoluted tubule during saline loading. Because of the nature of the split droplet technique, the increase in distal absorption stimulated by saline infusion can be dissociated from simultaneous changes caused by the infusion in glomerular filtration, tubular flow, and the composition of tubular fluid in the segment of nephron studied. Changes in tubular diameter as a cause of increased distal absorption are also excluded by measurements of the diameter of the oil-filled tubule, which was unaffected by saline loading. Why increased reabsorption in the distal tubule appears along with decreased proximal sodium reabsorption as extracellular fluid is expanded is not yet clear.

\section{Acknowledgments}

We are grateful to Janet Albrecht, Dorothy Smith, and Nadia Myketey for their expert technical assistance.

\section{References}

1. De Wardener, H. E., I. H. Mills, W. F. Clapham, and C. J. Hayter. Studies on the efferent mechanism of the sodium diuresis which follows the administration of intravenous saline in the dog. Clin. Sci. 1961, 21, 249.

2. Levinsky, N. G., and R. C. Lalone. The mechanism of sodium diuresis after saline infusion in the dog. J. clin. Invest. 1963, 42, 1261.

3. Dirks, J. H., W. J. Cirksena, and R. W. Berliner. The effect of saline infusion on sodium reabsorption by the proximal tubule of the dog. J. clin. Invest. 1965, 44, 1160.

4. Cortney, M. A., M. Mylle, W. E. Lassiter, and C. W. Gottschalk. Renal tubular transport of water, solute, and $\mathrm{PAH}$ in rats loaded with isotonic saline. Amer. J. Physiol. 1965, 209, 1199.

5. Wirz, H. Der osmotische Druck in den corticalen Tubuli der Rattenniere. Helv. physiol. pharmacol. Acta 1956, 14, 353.

6. Steinhausen, M. Eine Methode zur Differenzierung proximaler und distaler Tubuli der Nierenrinde von Ratten in vivo und ihre Anwendung zur Bestimmung tubularer Stromungsgeschwindigkeiten. Pflügers Arch. ges. Physiol. 1963, 277, 23.

7. Gertz, K. H., J. A. Mangos, G. Braun, and H. D. Pagel. On the glomerular tubular balance in the rat kidney. Pflügers Arch. ges. Physiol. 1965, 285, 360 .

8. Gertz, K. H. Transtubulare, Natriumchloridflusse und Permeabilitat fur Nichtelektrolyte im proximalen und distalen Konvolut der Rattenniere. Pflügers Arch. ges. Physiol. 1963, 276, 336.

9. Flanigan, W. J., and D. E. Oken. Renal micropuncture study of the development of anuria in the rat 
with mercury-induced acute renal failure. J. clin. Invest. 1965, 44, 449.

10. Hartroft, P. M., and W. S. Hartroft. Studies on renal juxtaglomerular cells. I. Variations produced by sodium chloride and desoxycorticosterone acetate. J. exp. Med. 1953, 97, 415.

11. Hartroft, P. M., and W. S. Hartroft. Studies on renal juxtaglomerular cells. II. Correlation of the degree of granulation of juxtaglomerular cells with width of the zona glomerulosa of the adrenal cortex. J. exp. Med. 1955, 102, 205.

12. Pitcock, J. A., P. M. Hartroft, and L. H. Newmark. Increased renal pressor activity (renin) in sodium deficient rats and correlation with juxtaglomerular cell granulation. Proc. Soc. exp. Biol. (N. Y.) $1959,100,868$.

13. Janecek, J., L. Tobian, M. Otis, and J. Huneke. Studies of renin and juxtaglomerular cells, components of a regulating system in the kidney. Fed. Proc. 1960, 19, 100.

14. Landwehr, D. M., R. M. Klose, and G. Giebisch. Micropuncture study of sodium reabsorption in saline-loaded rats. Fed. Proc. 1966, 25, 460.

15. Rector, F. C., Jr., J. C. Sellman, M. Martinez-Maldonado, and D. W. Seldin. The mechanism of suppresion of proximal tubular reabsorption by saline infusion. J. clin. Invest. 1967, 46, 47.

16. Lichardus, B., and J. W. Pearce. Evidence for a humoral natriuretic factor released by blood volume expansion. Nature (Lond.) 1966, 209, 407.

17. Johnston, C. I., and J. O. Davis. Evidence from cross circulation studies for a humoral mechanism in the natriuresis of saline loading. Proc. Soc. exp. Biol. (N. Y.) 1966, 121, 1058.

18. Leyssac, P. P., U. V. Lassen, and J. H. Thaysen. Inhibition of sodium transport in isolated renal tissue by angiotensin. Biochim. biophys. Acta (Amst.) 1961, 48, 602.

19. Leyssac, P. P. The in vivo effect of angiotensin on the proximal tubular reabsorption of salt in rat kidneys. Acta physiol. scand. 1964, 62, 436.

20. Nagel, W., M. Horster, M. Wahl, K. Thurau, and V. Schnermann. Die tubulare Resorptionskapazität fur isotone $\mathrm{Na}-\mathrm{Cl}$-Losung bei unterschiedlichen Glomerulumfiltraten und unter Angiotensineinwirkung. Pflügers Arch. ges. Physiol. 1966, 291, R60.
21. Rector, F. C., Jr., F. P. Brunner, and D. W. Seldin. Mechanism of glomerulotubular balance. I. Effect of aortic constriction and elevated ureteropelvic pressure on glomerular filtration rate, fractional reabsorption, transit time, and tubular size in the proximal tubule of the rat. J. clin. Invest. 1966, 45, 590.

22. Brunner, F. P., F. C. Rector, Jr., and D. W. Seldin. Mechanism of glomerulotubular balance. II. Regulation of proximal tubular reabsorption by tubular volume, as studied by stopped-flow microperfusion. J. clin. Invest. 1966, 45, 603 .

23. Landwehr, D. M., and R. M. Klose. Micropuncture study of sodium in saline loaded rats. Proc. int. Congr. Nephrol. 1966, 3, 227.

24. Selkurt, E. E. Effect of pulse pressure and mean arterial pressure modification on renal hemadynamics and electrolyte and water excretion. Circulation 1951, 4, 541.

25. Handley, C. A., and J. H. Moyer. Unilateral renal adrenergic blockage and the renal response to vasopressor agents and to hemorrhage. J. Pharmacol. exp. Ther. 1954, 112, 1.

26. McDonald, S. J., and H. F. de Wardener. The relationship between the renal arterial perfusion pressure and the increase in sodium excretion which occurs during an infusion of saline. Nephron 1965, 2, 1.

27. Selkurt, E. E., I. Womack, and W. N. Dailey. Mechanism of natriuresis and diuresis during elevated renal arterial pressure. Amer. J. Physiol. 1965, 209, 95.

28. Tobian, L., K. Coffee, D. Ferreira, and J. Meuli. The effect of renal perfusion pressure on the net transport of sodium out of distal tubular urine as studied with the stop-flow technique. J. clin. Invest. 1964, 43, 118.

29. Malnic, G., R. M. Klose, and G. Giebisch. Microperfusion study of distal tubular potassium and sodium transfer in rat kidney. Amer. J. Physiol. 1966, 211, 548.

30. Rector, F. C., Jr., G. Van Giesen, F. Kiil, and D. W. Seldin. Influence of expansion of extracellular volume on tubular reabsorption of sodium independent of changes in glomerular filtration rate and aldosterone activity. J. clin. Invest. 1964, 43, 341. 